\title{
Byram Ferry (16B017): A Middle to Late Caddo Period Mound Site in the Red River Floodplain, Northwest Louisiana
}

Jeffery S. Girard

Northwestern State University of Louisiana

Follow this and additional works at: https://scholarworks.sfasu.edu/ita

Part of the American Material Culture Commons, Archaeological Anthropology Commons, Environmental Studies Commons, Other American Studies Commons, Other Arts and Humanities Commons, Other History of Art, Architecture, and Archaeology Commons, and the United States History Commons

Tell us how this article helped you.

This Article is brought to you for free and open access by the Center for Regional Heritage Research at SFA ScholarWorks. It has been accepted for inclusion in Index of Texas Archaeology: Open Access Gray Literature from the Lone Star State by an authorized editor of SFA ScholarWorks. For more information, please contact cdsscholarworks@sfasu.edu. 
Byram Ferry (16B017): A Middle to Late Caddo Period Mound Site in the Red River Floodplain, Northwest Louisiana

\section{Creative Commons License}

\section{(c) (1) \&}

This work is licensed under a Creative Commons Attribution-NonCommercial 4.0 International License 


\title{
Byram Ferry (16BO17): A Middle to Late Caddo Period Mound Site in the Red River Floodplain, Northwest Louisiana
}

\author{
Jeffrey S. Girard \\ Regional Archaeology Program \\ Northwestern State University of Louisiana
}

\section{INTRODUCTION}

One of the few remaining Caddo mounds in northwest Louisiana is located at the Byram Ferry site (16BO17) in northern Bossier Parish near the Arkansas state line (Figure 1). Until recently, a brief description by Clarence B. Moore (1912) and a few comments by Clarence H. Webb in his undated and unpublished field notes constituted the only information about the site available to archeological researchers (Weinstein et al. 2003:64). A collection of sherds and one intact vessel from Byram Ferry are present in the Ralph McKinney collection currently on loan to the History Center at the Bossier Parish Library in Bossier City, Louisiana. Examination of this collection in 2003 prompted us to re-locate the site and conduct limited subsurface tests to determine whether or not intact cultural deposits remain. In this article I summarize earlier fieldwork, describe the 2003 testing, and present a descriptive analysis of the collections. The testing demonstrated that undisturbed buried cultural deposits are present at Byram Ferry. Represented ceramic types relate to the Middle Caddo period (Bossier phase) and the Late Caddo period (Belcher phase). Two radiocarbon assays suggest occupation took place in the 15 th century A.D.

\section{Early Investigations}

On his 1912 Red River expedition, Clarence B. Moore (1912:525) stopped at Byram Ferry and described two mounds "within a few yards of each other." The largest mound was less than $9 \mathrm{ft}$. high, $132 \mathrm{ft}$. across at the base (north to south), and oblong with rounded corners. The summit had a flat top and was $80 \mathrm{ft}$. across (north to south). Moore dug an unspecified number of holes into the mound and, on the north side, found a layer of clay over fine sand. The entire southern portion of the mound was of sand. No bone or artifacts were recovered. The smaller mound, constructed entirely of sand, was $4 \mathrm{ft}$. high, had a circular base $75 \mathrm{ft}$. in diameter, and a summit $35 \mathrm{ft}$. in diameter. Moore excavated an $18 \mathrm{ft}$. square pit and several trial holes in the small mound. He encountered a 6-inch thick layer of dark material that was $4 \mathrm{ft} .10$ inches from the surface of the summit. Nothing was found except "one rude arrowhead of flint."

Clarence $\mathrm{H}$. Webb later visited the site and made a brief description in his undated field notes. At that time, the site was split between the Adams and Petty Plantations and Byram Ferry was known as Missionary Ferry (a name that still appears on USGS topographic maps). Webb noted that the site appeared to be adjacent to an old Red River channel, less than a mile from the active channel. The mound on the Adams property had a tenant house on the summit. Webb (n.d.) stated that "considerable washing around the sides has exposed 1 feet, the 


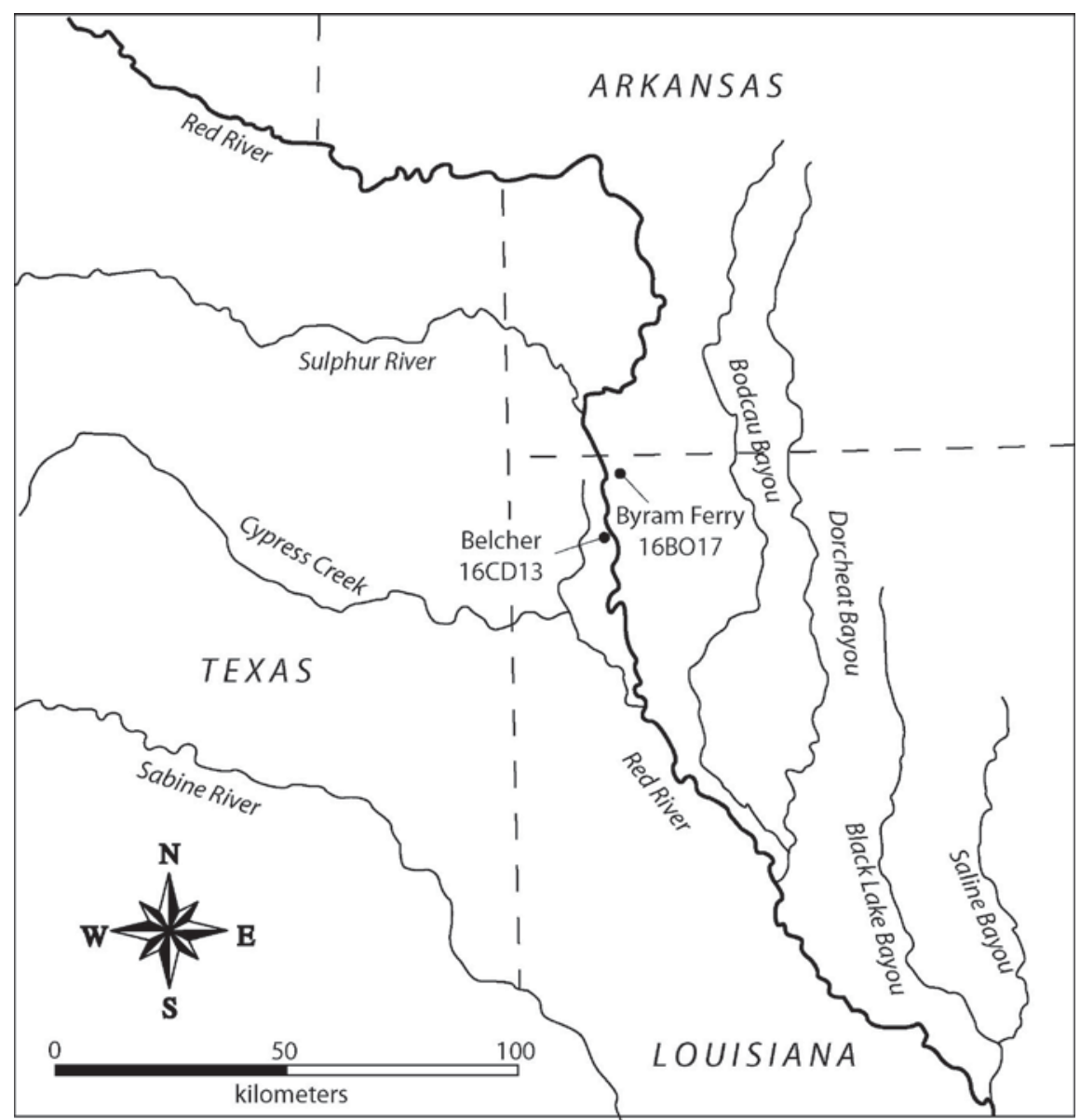

Figure 1. Location of the Byram Ferry and Belcher sites.

top 6 to 10 inches of which is a black midden with pottery, charred wood, shell, clay daub, etc —apparently a house floor. About a dozen large sherds of Belcher Ridged type pottery found in situ." I assume that the Adams mound was the larger of the two noted by Moore. The second mound was located in the Petty field about 100 yards away and Webb made a surface collection from the surrounding area. According to Webb's notes, the mound was partially plowed down but seemed to be about $100 \mathrm{ft}$. in diameter and $5 \mathrm{ft}$. high.

During the middle 1950s, a group of local residents led by Mary Helen (Hattie) Horneman of Plain Dealing, Louisiana, excavated the remaining portions of the smaller mound. The present landowner was a child at the time but remembers that the entire mound area was excavated several feet below the present surface. Apparently involved in the work was Ralph McKinney, a local rancher who had worked with Webb at the Mounds Plantation site (Webb and McKinney 1975). McKinney retained one intact vessel (Figure 2), a large sample of sherds, and a few stone artifacts from the excavations. It is likely that the collection does not include all of the material from the work; other participants apparently kept some items as well. McKinney made a few notes and sketches, but the information is too vague to determine much about the nature of the deposits, or about the possible presence of features within or beneath the mound.

The Byram Ferry site was visited in the 1970s during a survey of the Red River floodplain that was described in a report to the U.S. Army Corps of Engineers (Gulf South Research Institute [GSRI] 1975). A tenant house remained on the existing mound when visited by the GSRI survey crew. They interviewed Ralph McKinney, 


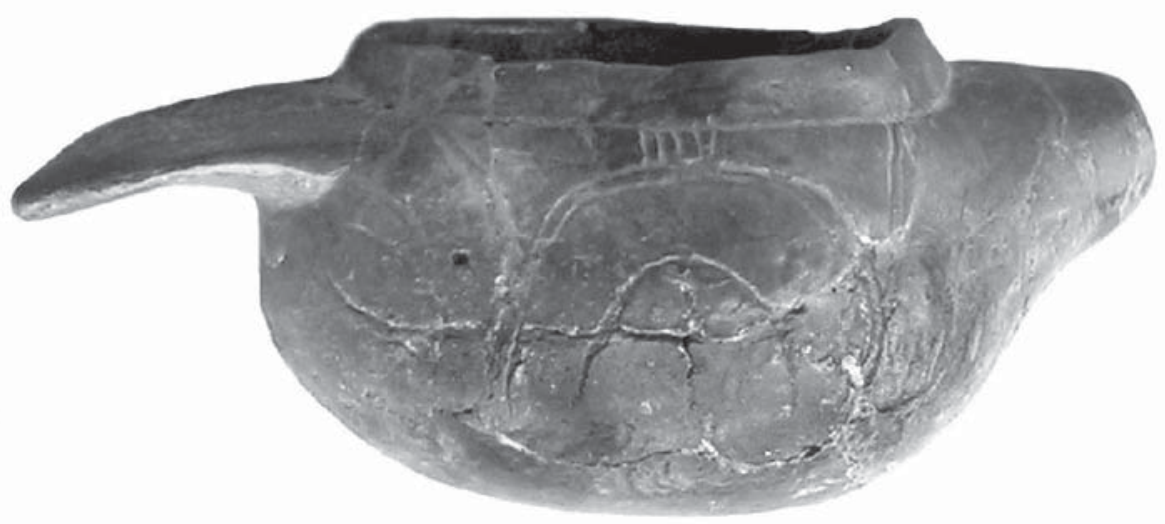

Figure 2. Engraved effigy vessel from the Byram Ferry site in the McKinney Collection.

who stated that numerous pottery vessels were recovered from a burial pit north of the mound (apparently within or beneath the small mound). Other local sources suggested that skeletal remains were exposed during levee construction west of the mound. The GSRI report noted that alluvium had buried the site surface. The field crew collected four brushed sherds and one engraved sherd (a carinated bowl fragment).

\section{Investigations}

In January 2003, Louisiana Archaeological Society members Louis Baker, Nita Cole, Mike Montgomery, and I visited the site. The mound still had the general configuration noted by Moore-it slopes up from south to north and has a flat summit (Figure 3). On the north, the summit was a little over $1 \mathrm{~m}$ high, but was only about $50 \mathrm{~cm}$ high to the south (somewhat smaller than Moore's description). The outline was generally quadrilateral, but the peripheries were eroded. The mound was oriented roughly southwest to northeast and about $35 \mathrm{~m}$ long and $25 \mathrm{~m}$ across, similar in size to Moore's estimate. The ruins of the earlier reported tenant house remained on the north end of the mound.

The landowner of the existing mound expressed interest in protecting the site, but did not want it mapped or any subsurface investigations on the property. However, the landowner who owns the property to the north, where the smaller mound was located, granted permission for Baker and I to carry out shovel tests to determine whether or not intact deposits remain.

Initially, a bucket auger was used to test for remnants of the excavated mound. Subtle variations in the color and texture of the deposits were noted, but we could not detect a buried surface. We then decided to excavate a series of $50 \times 50 \mathrm{~cm}$ shovel tests. The first two were placed in the former mound area (Figure 4). A thin A soil horizon was underlain by three distinct depositional zones. The upper zone was a homogeneous, dark reddishbrown, very fine sandy loam that extended to between 16 and $20 \mathrm{~cm}$ below the surface (bs). It was separated by an abrupt smooth break to a stratified deposit, generally similar in color and texture, but with lenses and narrow strata of silt loam. This second zone contained a small number of artifacts. An abrupt smooth boundary separated this zone from an underlying, brown, fine sand deposit, that was homogeneous and without artifacts. An auger test placed at the base of the shovel test indicated that the fine sand extends to $1.9 \mathrm{~m}$ bs, at which point slightly redder, saturated deposits were encountered. On the southeast, the boundary between the second and 


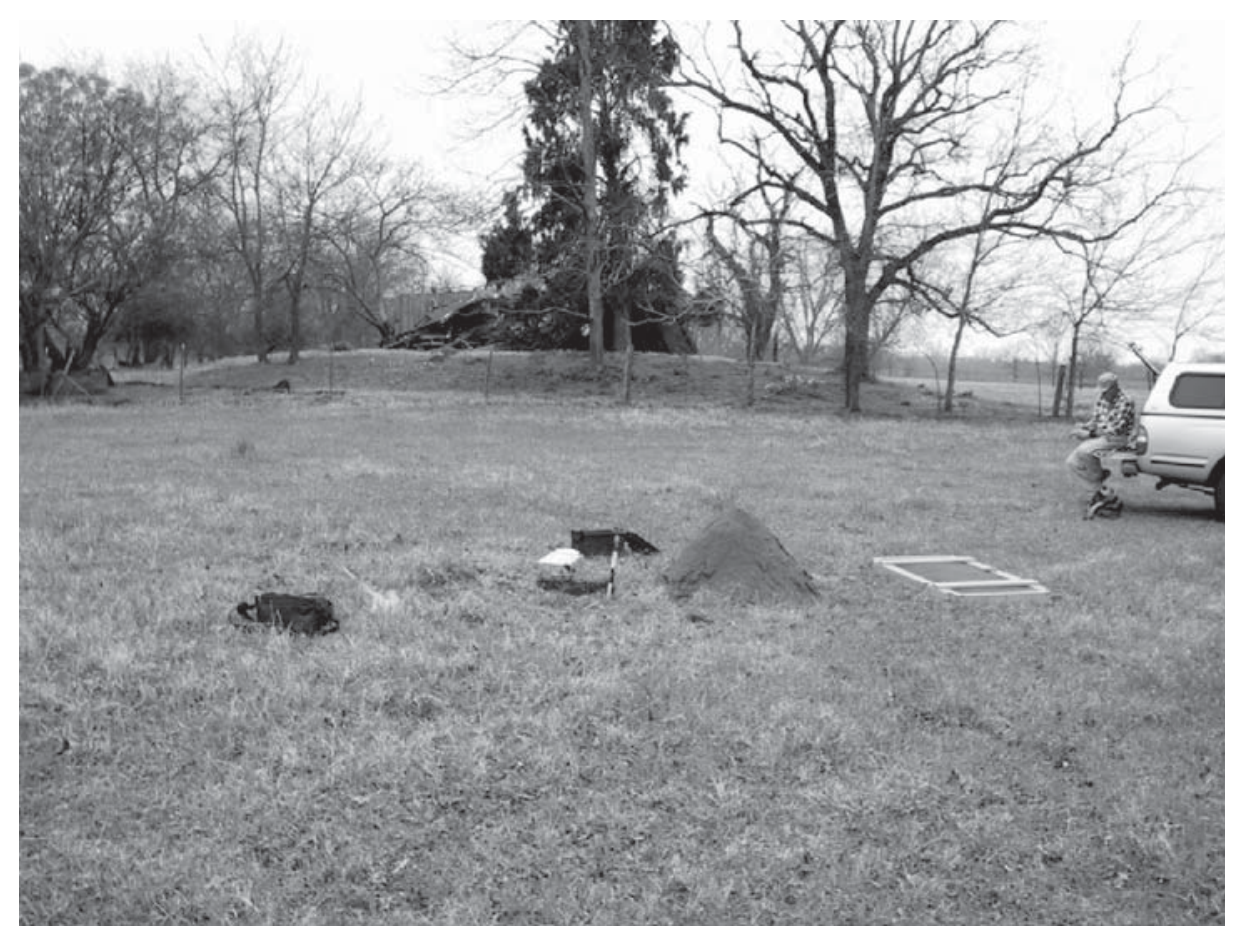

Figure 3. Looking south at the remaining mound at the Byram Ferry site. Shovel Test 4 is in the foreground.

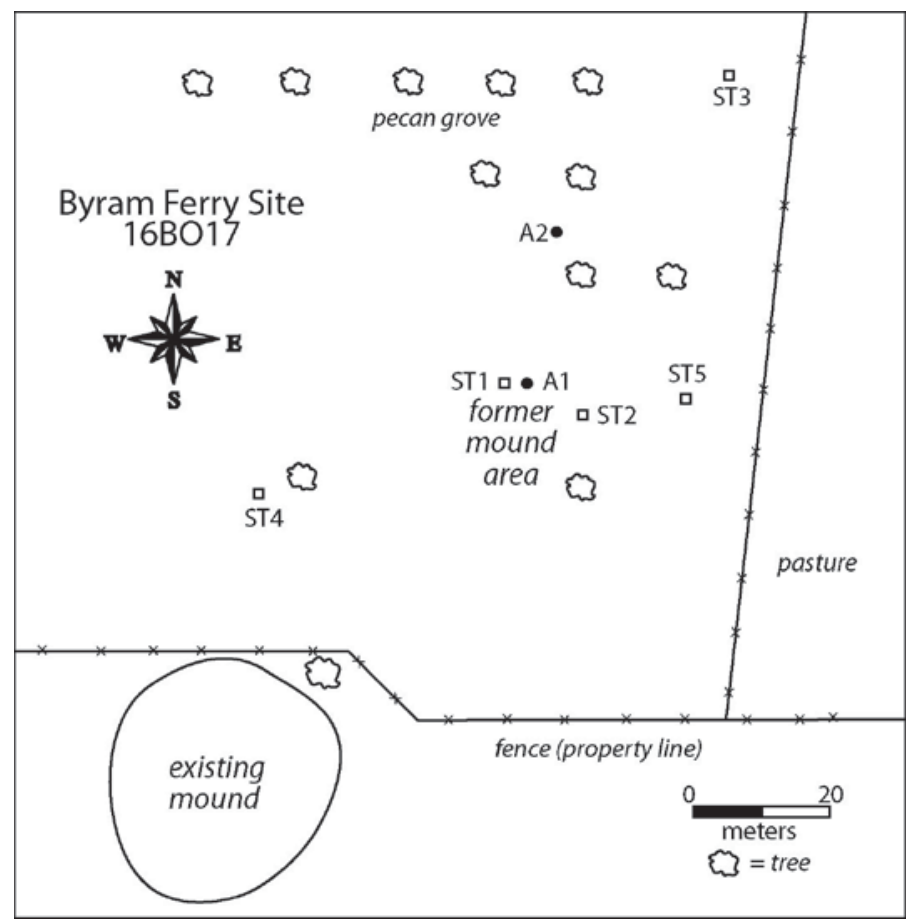

Figure 4. Sketch map of the Byram Ferry site. 
third zones was $40 \mathrm{~cm}$ bs, but this dipped to $60 \mathrm{~cm}$ bs in the other portions of the unit. The middle zone appeared to have partially washed in (perhaps backfilled) and almost undoubtedly represented the old excavation pit. Deposits probably were not screened and the presence of a few small artifacts was not surprising.

The final three shovel tests were excavated away from the former mound area. All had similar, undisturbed soil profiles. Beneath a thin A soil horizon was dark reddish-brown silt loam alluvium to about $30 \mathrm{~cm} \mathrm{bs}$. An abrupt change marked a buried A horizon consisting of dark brown fine sandy loam. A transition to a slightly redder and finer-textured $\mathrm{B}$ horizon was evident between 55 and $70 \mathrm{~cm}$ bs. Artifacts were recovered only within the $2 \mathrm{~A}$ horizon.

Several small lumps of wood charcoal were recovered from Shovel Test 2. The charcoal was submitted to the Center for Isotope Studies at the University of Georgia for radiocarbon analysis and resulted in an age of $420 \pm 40$ B.P. (UGA12294, wood charcoal, 13C=-28.09). A second sample was submitted of charcoal in the McKinney collection that reportedly came from the mound. The result was $470 \pm 40$ B.P. (UGA12295, wood charcoal, $13 \mathrm{C}=-24.92$ ). Calibration of the assays strongly suggests that the site was occupied during the 15 th century A.D. (Table 1), a result that conforms to our expectations given the range of pottery types present in the McKinney and Webb collections.

\section{Pottery in the McKinney and Webb Collections}

A little over 1000 sherds are present in the McKinney and Webb collections from the Byram Ferry site. Since Caddo potters often treated vessel bodies and rims as separate design fields and vessels often break along the rim-body juncture, body and rim sherds are classified separately in this study (Tables 2 and 3). Included with rims are specimens where the lip is intact as well as those that can be determined to be rims by their shape. All sherds from the McKinney collection probably came from excavation of the small mound, whereas those in the Webb collection are from the surface near the mound.

\begin{tabular}{|c|c|c|c|}
\hline Lab No. & Radiocarbon age & 1 Sigma Range & 2-Sigma Range \\
\hline \multirow{2}{*}{ UGA12294 } & $420 \pm 40$ & $1433-1491(0.959)$ & $1419-1522(0.843)$ \\
\hline & & $1603-1609(0.041)$ & $1572-1627(0.157)$ \\
\hline \multirow[t]{2}{*}{ UGA12295 } & $470 \pm 40$ & $1413-1451(1.000)$ & $1333-1338(0.006)$ \\
\hline & & & $1399-1488(0.994)$ \\
\hline
\end{tabular}

\section{Belcher Ridged and Pease Brushed Incised}

These types constitute the bulk of Caddo utilitarian pottery for the Middle and Late Caddo periods in northwest Louisiana. Belcher Ridged was described by Webb (1959:136-139) as characterized by:

Vertical ridging, made by pushing up clay on each side of troughs with a round-tipped tool, possibly at times with the finger, or less likely, by marking with a notched tool, while the clay was soft. On a few vessels, the ridges peel or flake off, suggesting that soft mix was applied to a harder surface, then tooled. Incising or brushing on outer rim surfaces.

Webb suggested that the type developed during the Bossier focus (Middle Caddo period), possibly as a variation on Pease Brushed Incised. Pease differs in that "the ridges are heavier, nearly always appliquéd, spaced further apart, notched, and the intervening spaces are further roughened by brushing or incising" (Webb 1959:139). In 


\begin{tabular}{|c|c|c|c|}
\hline Body Sherds & $\begin{array}{l}\text { McKinney } \\
\text { Collection }\end{array}$ & $\begin{array}{c}\text { Webb } \\
\text { Collection }\end{array}$ & Total \\
\hline Belcher Ridged, var. Belcher & 12 & 14 & 26 \\
\hline Belcher Ridged, var. Byram Ferry & 14 & 24 & 38 \\
\hline Belcher Ridged, var. Gore & 11 & 3 & 14 \\
\hline Pease Brushed-Incised & 33 & 16 & 49 \\
\hline Haley Complicated Incised & 1 & 0 & 1 \\
\hline Harleton Appliqued & 1 & 0 & 1 \\
\hline miscellaneous brushed & 81 & 73 & 154 \\
\hline miscellaneous appliqué & 10 & 0 & 10 \\
\hline miscellaneous ridged/brushed & 17 & 15 & 32 \\
\hline Foster Trailed Incised & 7 & 1 & 8 \\
\hline Mound Tract Incised and Brushed & 1 & 0 & 1 \\
\hline Cowhide Stamped & 2 & 0 & 2 \\
\hline miscellaneous incised & 3 & 1 & 4 \\
\hline Glassell Engraved & 2 & 0 & 2 \\
\hline Hodges Engraved & 1 & 1 & $\overline{2}$ \\
\hline Belcher Engraved & 1 & 0 & 1 \\
\hline miscellaneous engraved & 30 & 18 & 48 \\
\hline undecorated, red slipped & 1 & 0 & $\overline{1}$ \\
\hline undecorated, polished & 92 & 8 & 100 \\
\hline Undecorated & 242 & 213 & 455 \\
\hline Total Undecorated & 335 & 221 & 556 \\
\hline
\end{tabular}
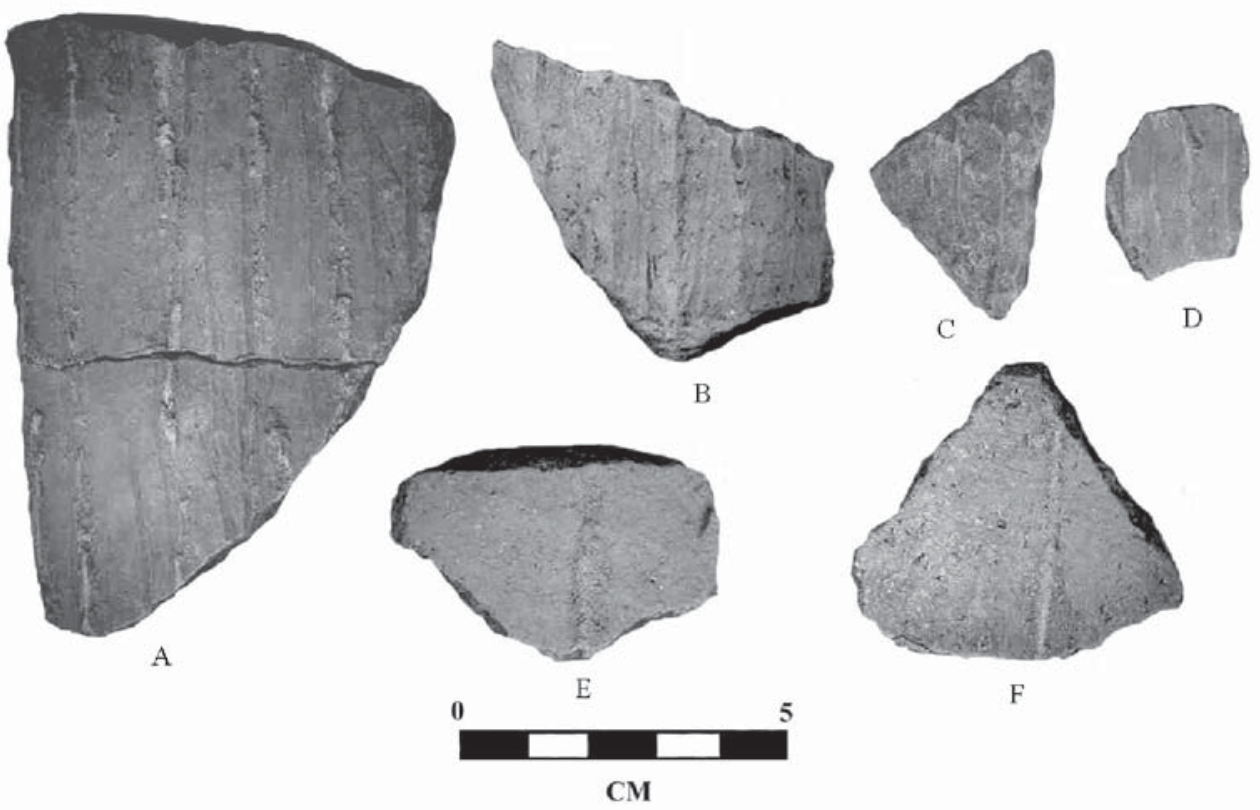

F

Figure 5. Belcher Ridged sherds: var. Byram Ferry (a-b), var. Belcher (c-d), and var. Gore (e-f) 


\begin{tabular}{|l|c|c|c|}
\hline \multicolumn{1}{|c|}{ Table 3. Rim sherds in the McKinney and Webb Collections. } \\
\hline & $\begin{array}{c}\text { McKinney } \\
\text { Collection }\end{array}$ & $\begin{array}{c}\text { Webb } \\
\text { Collection }\end{array}$ & Total \\
\hline brushed, horizontal & 18 & 14 & 32 \\
\hline brushed, diagonal & 2 & 8 & 10 \\
\hline brushed, vertical & 4 & 3 & 7 \\
\hline incised, horizontal & 1 & 1 & 2 \\
\hline incised, vertical & 3 & 2 & 5 \\
\hline incised, diagonal & 1 & 0 & 1 \\
\hline miscellaneous ridged & 1 & 5 & 6 \\
\hline neck banded & 1 & 0 & 1 \\
\hline Punctated & 3 & 0 & 3 \\
\hline Engraved & 9 & 6 & 15 \\
\hline Undecorated & 12 & 3 & 15 \\
\hline Total & 55 & 42 & 97 \\
\hline
\end{tabular}

a later paper, Webb acknowledged some problems with differentiating the two types:

Difficulties in typing sherds, insofar as Pease type is concerned, arise in those instances where sharp vertical ridges, like those of Belcher Ridged type, are widely spaced and have vertical brushing between them. This, in fact, may have been the method by which the type Belcher Ridged originated as a variant of Pease type. In doubtful instances, we attempt to determine whether any scoring or irregularities in the valleys were intentional or were incidental to production of the ridges. By Belcher Focus times, the technique of producing Belcher Ridged with uniform, closely placed ridges and smooth valleys had improved to the extent that typing problems are rare (Webb 1983:185).

The ambiguity in the type definitions is particularly apparent in the Byram Ferry collections. For descriptive purposes, I suggest sub-dividing Belcher Ridged into three varieties that may further our understanding of ceramic chronology in the region. In the Byram Ferry collection, many sherds have the thin, unnotched ridges of the type Belcher Ridged, but also have distinct vertical brushing between the ridges. These are classified as a distinct variety of Belcher Ridged that I call var. Byram Ferry (Figure 5a-b). Typologically, they are intermediate between Pease Brushed Incised and Belcher Ridged (and could be classified with either type). The fifteenth century dates from Byram Ferry corroborate Webb's suggestion that Belcher Ridged represents a variant of Pease Brushed Incised that became dominant in the Late Caddo period (ca. A.D. 1500-1700). Sherds lacking brushing between the ridges, that conform more closely to Webb's (1959) type definition, I classify as var. Belcher (Figure 5c-d).

Another variation on the general Belcher Ridged theme are sherds that have smooth ridges formed like those in Belcher Ridged but placed at wide intervals $(>1.5 \mathrm{~cm})$ with no intervening brushing. The specimens lack the "troughs" of the standard Belcher Ridged type. It may be beneficial to classify these specimens separately as well, and here I call them Belcher Ridged, var. Gore (Figure 5e-f).

Relatively tall, horizontally brushed jar rims (Form A) are common at the Byram Ferry site (Table 4; Figures 6 and 7). These rims commonly occur on Pease Brushed-Incised vessels. Short, flared rims (Form B) with vertical or diagonal incised or brushed lines are characteristic of Belcher Ridged and Karnack Brushed jars. Some Belcher Ridged vessels have inverted rims, usually with a rolled lip (Form C), with ridging usually extending almost to the lip. Schambach and Miller (1984:120) used this trait as diagnostic of the classic variety of Belcher Ridged, and separated vessels with incised, brushed, or punctated rims as var. Wilson's Island. 


\begin{tabular}{|l|c|c|c|c|c|c|c|r|r}
\hline \multicolumn{1}{|c}{ Table 4. Rim forms (see Figure 6). } \\
\hline \multicolumn{1}{r|}{ Rim Form: } & $\mathrm{A}$ & $\mathrm{B}$ & $\mathrm{C}$ & $\mathrm{D}$ & $\mathrm{E}$ & $\mathrm{F}$ & $\mathrm{G}$ & $\mathrm{NC}$ & Total \\
\hline brushed, horizontal & 10 & 0 & 1 & 3 & 1 & 0 & 0 & 17 & 32 \\
\hline brushed, diagonal & 5 & 0 & 1 & 1 & 0 & 0 & 0 & 3 & 10 \\
\hline brushed, vertical & 2 & 2 & 0 & 0 & 0 & 0 & 0 & 3 & 7 \\
\hline incised, horizontal & 1 & 0 & 0 & 0 & 1 & 0 & 0 & 0 & 2 \\
\hline incised, vertical & 0 & 4 & 0 & 0 & 0 & 0 & 0 & 1 & 5 \\
\hline incised, diagonal & 0 & 1 & 0 & 0 & 0 & 0 & 0 & 0 & 1 \\
\hline miscellaneous ridged & 0 & 0 & 2 & 0 & 0 & 1 & 0 & 3 & 6 \\
\hline Neck banded & 1 & 0 & 0 & 0 & 0 & 0 & 0 & 0 & 1 \\
\hline punctated & 2 & 0 & 0 & 0 & 0 & 0 & 1 & 0 & 3 \\
\hline engraved & 2 & 1 & 1 & 1 & 6 & 1 & 0 & 3 & 15 \\
\hline undecorated & 1 & 0 & 0 & 2 & 4 & 0 & 1 & 7 & 15 \\
\hline Total & 24 & 8 & 5 & 7 & 12 & 2 & 1 & 37 & 97 \\
\hline
\end{tabular}

$\mathrm{NC}=$ Not Classified

\section{Haley Complicated Incised}

One sherd has notched appliquéd ridges in multiple directions with brushing and linear punctations between the ridges (Figure 8g). The specimen appears to relate to the type Haley Complicated Incised (Suhm and Jelks 1962:59). This type is thought to have been made primarily in the Early and Middle Caddo periods and seems early given the nature of the rest of the collection.

\section{Harleton Appliqued}

A single body sherd has appliqué ridges in a nested diamond pattern (Figure $8 \mathrm{~h}$ ) and appears to relate to the type Harleton Appliqued (Suhm and Jelks 1962:65). This type is associated most closely with the Late Caddo period Titus phase in the Big Cypress Creek drainage of northeast Texas.

\section{Miscellaneous Brushed Sherds}

Webb classified vertical brushed vessels that have essentially the same vessel shapes as Belcher Ridged jars in the type Karnack Brushed. Originally Karnack Brushed was limited to vertical brushed vessels. Webb (1983:193) later pointed out the difficulty with determining the orientation of brushing on most sherds and, in his paper on the Bossier focus, classified all (non-ridged) brushed sherds as Bossier Brushed. At Byram Ferry, it appears that most of the brushing is vertical, but too many specimens are ambiguous to classify sherds by orientation.

\section{Miscellaneous Ridged and Brushed/Ridged}

A small number of ridged specimens have portions of ridges but were too small or broken in a manner that they could not be related to one of these groups. These specimens are tabulated as miscellaneous ridged (where no brushing is visible) or brushed/ridged. 


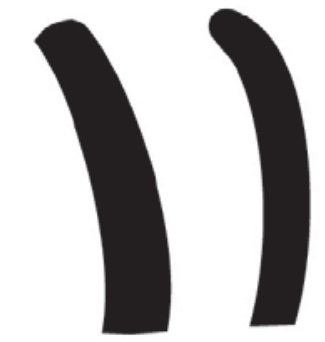

A

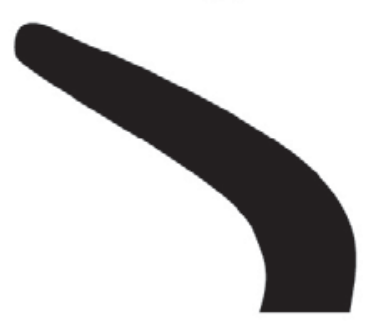

D
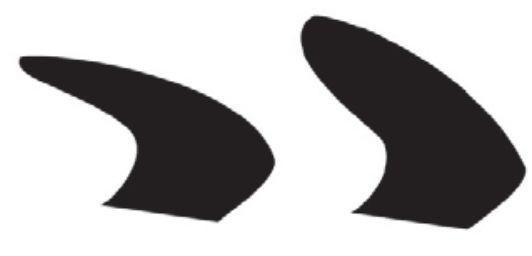

B

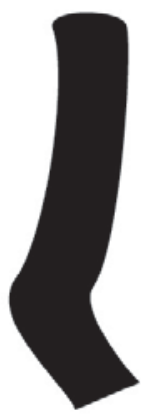

E

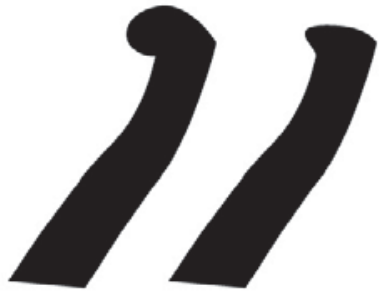

C

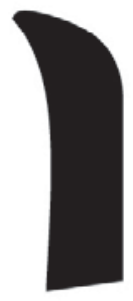

G

Figure 6. Rim forms for the Byram Ferry Site.
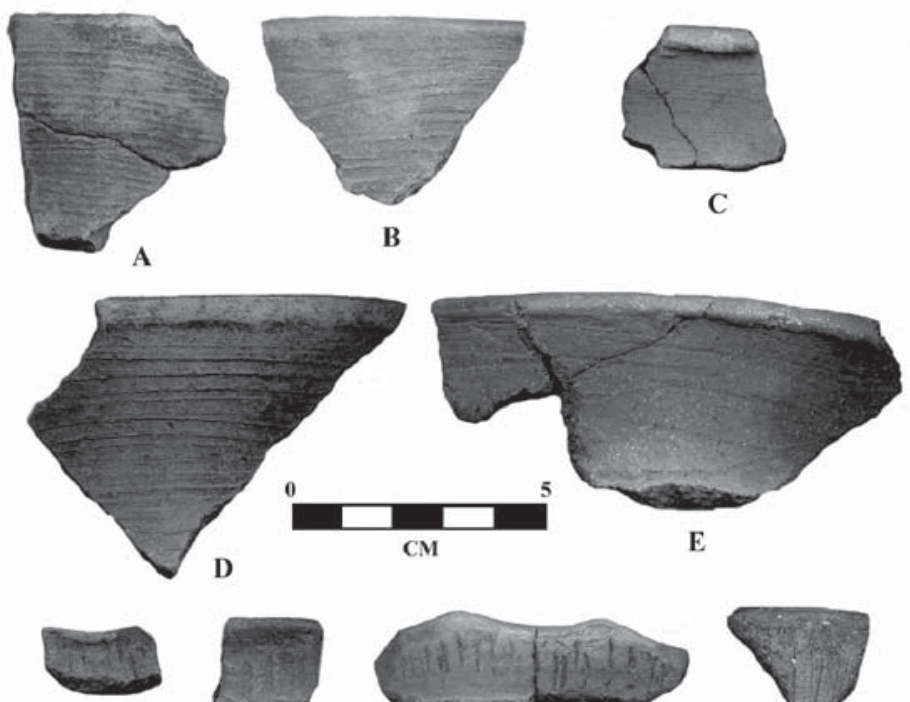

F

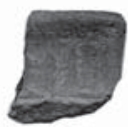

G

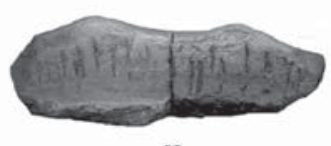

H

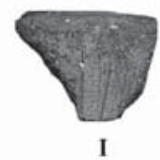

Figure 7. Brushed and incised rim sherds. 

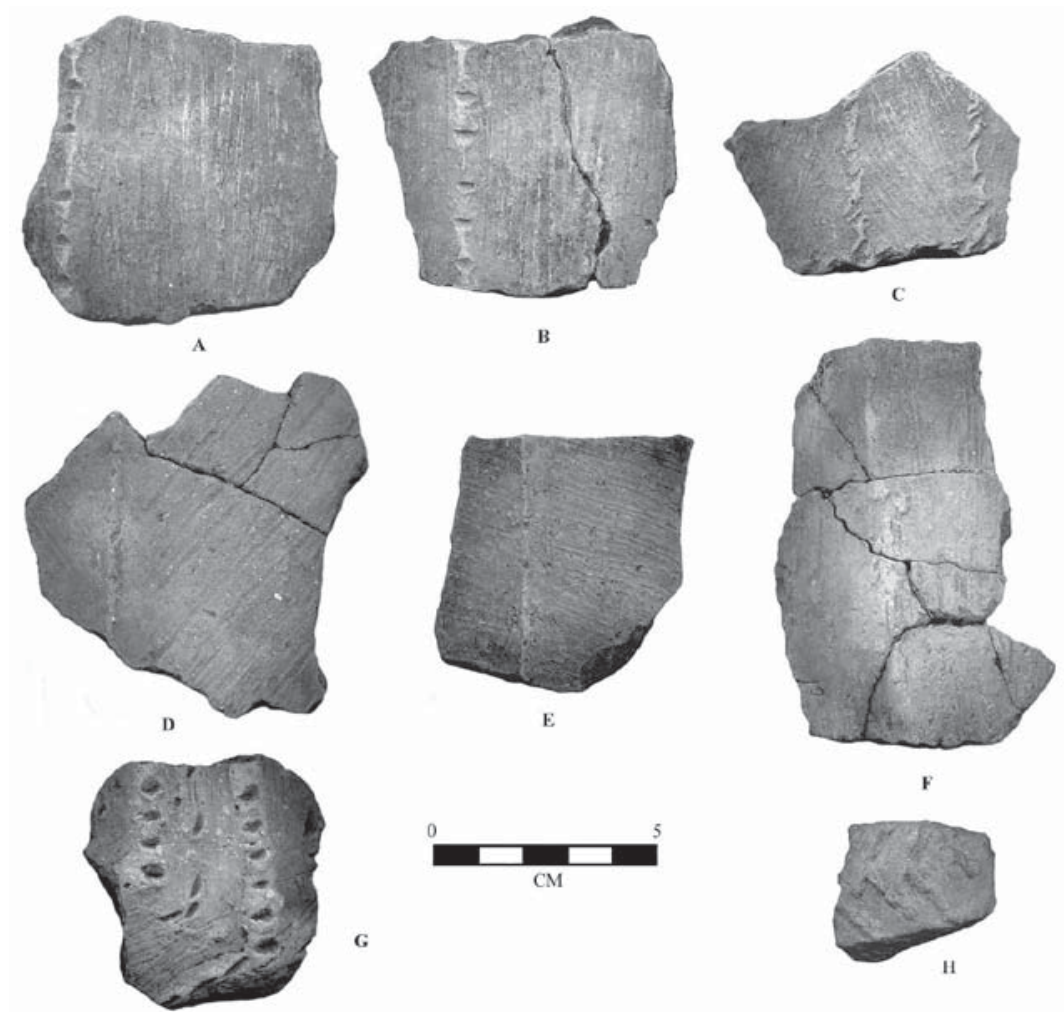

Figure 8. Brushed and ridged sherds: Pease Brushed Incised (a-f), Haley Complicated Incised (g), Harleton Appliqued (h).

\section{Avery Engraved}

One rim sherd has multiple horizontal lines on a polished black surface. The rim is tall and flares outward at the lip in a manner common on Avery Engraved vessels (this is a very tenuous classification). The sherd has fine-textured paste with no visible temper. The effigy vessel (see Figure 2) in the McKinney collection has a design that also resembles Avery Engraved.

\section{Belcher Engraved}

One body and one rim sherd appear to relate to the type Belcher Engraved. The body sherd (Figure 9g) has curvilinear engraved lines separated by short, dashed lines. The interior is rough and the sherd likely is from a bottle. The rim has the characteristic form of Belcher Engraved bowls with two horizontal engraved lines and a dashed line between. Both sherds have fine-textured paste with no obvious temper.

\section{Glassell Engraved}

Three rim and two body sherds are classified as Glassell Engraved (Figure 9d-f). All are from carinated bowls. One of the sherds has finely crushed bone in the paste. The rest have no visible temper. The sherds have rec- 


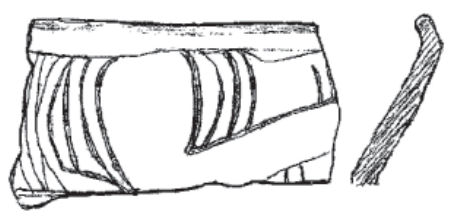

A

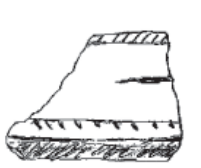

$\mathrm{D}$

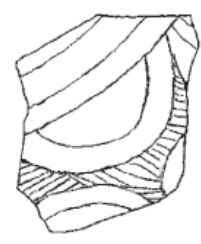

$\mathrm{H}$
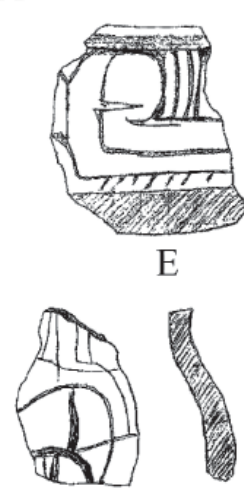

I

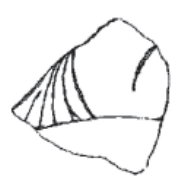

B

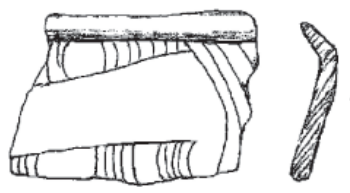

$\mathrm{C}$

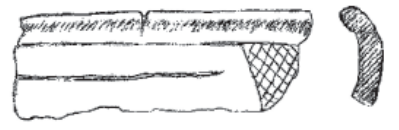

$\mathrm{F}$

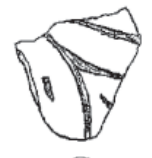

G

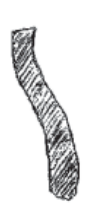

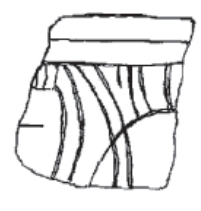

$\mathrm{J}$

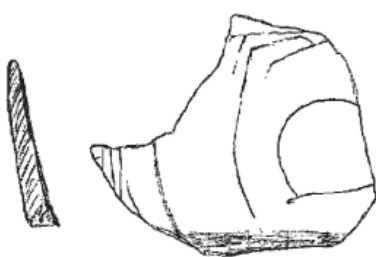

K

Figure 9. Selected engraved sherds: Hodges Engraved (a-c, h), Glassell Engraved (d-f), Belcher Engraved (g), miscellaneous engraved (i-k).

tilinear panels with parallel arcs characteristic of the type. Webb typed most specimens with cross-hatched zones (as in Figure 9f) with Maddox or Friendship Engraved rather than Glassell Engraved. However, several vessels typed as Glassell Engraved from the Belcher site (16CD13) (Webb 1959:Figure 118) have small crosshatched zones that separate panels.

\section{Hodges Engraved}

Three rims and one body sherd have negative scrolls separated by arcs or hatching (Figure 9a-c). All are on carinated bowls (the "body" sherd actually is part of a rim with the lip missing). There is some ambiguity with typing these specimens. Schambach and Miller (1984:Figure 11-36) classified a vessel with a similar design element as Glassell Engraved, var. McGee, and Suhm and Jelks (1962:Plate 27) include one vessel with a similar scroll in the type Glassell Engraved. However, this element seems to differ fundamentally from the horizontal scrolls or panels on most Glassell Engraved vessels, and to fit more closely to the Hodges Engraved type. Webb (1959: Figure 107c, f) typed similar vessels as Hodges Engraved. Admittedly, the arc-like hatching is reminiscent of Glassell.

Two other body sherds typed as Hodges Engraved have negative curvilinear zones separated by hatched bands (Figure 9h). Both have rough interiors and are likely to be from bottles. One appears to have sparse finely crushed bone in the paste. The rest of the Hodges Engraved sherds have no apparent temper.

\section{Miscellaneous Engraved}

The remaining engraved sherds cannot be related to specific types. Twenty-four have one or more straight lines (two are spurred or ticked), and 16 have multiple curvilinear lines (Figure 9i-j). Hatched zones are present on nine 
specimens and hatched bands on three. Two specimens have what appear to be portions of sloppy scrolls (Figure 9k).

\section{Foster Trailed Incised}

Seven punctated sherds probably are from tall rims of Foster Trailed Incised vessels. Because no distinct rim curvature is visible they have been tabulated with the body sherds. The sherds either have numerous small punctations (Figure 10a-b) or fingernail punctations in horizontal rows (Figure 10c-d). Three rims (e.g., Figure 10j) also have punctations in horizontal rows and may relate to this type. Two or the rims curve outward (Type A) and one is vertical (Type G). None of the rim diameters can be measured. The final sherd classified with this type has a trailed curvilinear line (Figure 10e). The body sherds are relatively thin (Table 5). Temper varies: three specimens have grog temper, three bone, one shell, and one has no visible temper.

Foster Trailed Incised first appeared at the Belcher site in Belcher 2 times and became common in the Belcher 3 houses (Webb 1959). The rims at Byram Ferry are suggestive of some of the earlier varieties at the Cedar Grove site (3LA97) in southwestern Arkansas (Schambach and Miller 1984). Foster Trailed Incised was abundant in the Belcher phase contexts at the Cedar Grove site, but appeared to diminish in importance in the Chakanina phase (ca. middle 17th century).

\section{Mound Tract Incised and Brushed}

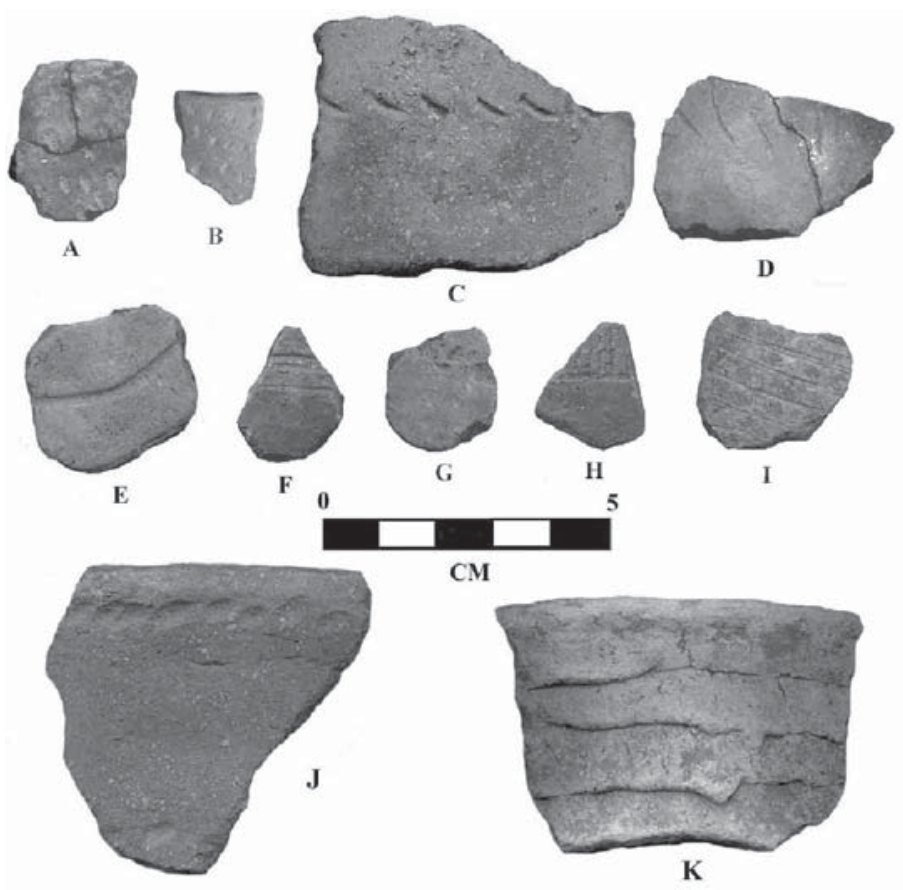

Figure 10. Miscellaneous decorated sherds: miscellaneous punctated (a-d), Foster Trailed (e), Mound Tract Incised and Brushed (f), Cowhide Stamped (g-h), miscellaneous incised (i), punctated rim (j), and neck-banded rim (k). 
One small sherd has a brushed band bordered by incised lines. This design element was initially included by Webb with the type Cowhide Stamped, but examples from the Ouachita River drainage later were separated by Kidder (1988) into a different type called Mound Tract Incised and Brushed. This type is present at the Belcher and McLelland sites. Although commonly thin and shell-tempered, the specimen from Byram Ferry is relatively thick and has grog temper.

\section{Cowhide Stamped}

Two sherds (Figure 10g-h) are classified as Cowhide Stamped. One has a rocker stamped band bordered by incised lines. The other has a simple stamped band without borders. Both specimens have well smoothed to lightly polished surfaces. One has grog temper and the other has no visible temper. Although both sherds are tabulated as body sherds, they are small and could be portions of rims. Cowhide Stamped appears restricted primarily to the Belcher phase (Late Caddo period), although the type is never abundant and not well dated.

\section{Miscellaneous incised}

Four body sherds have multiple, parallel incised lines (Figure 10i). None are large enough to relate to a specific type. Two have grog temper and two have bone temper.

Six of the eight incised rim sherds are on short, flared rims (Form B) and probably relate to Belcher Ridged or Karnack Brushed vessels. One exception is a small sherd with an incised horizontal line that appears to be on a carinated bowl rim. The second exception is a thick, Form A rim that has closely-spaced horizontal lines that could be considered as neatly brushed rather than incised.

\section{Red Slipped}

A single red-slipped sherd is present in the collection. Red slipping occurs throughout the Caddo prehistoric and early historic ceramic sequence but appears to have been more common in the Early and Middle Caddo periods. Late Caddo Titus phase sites in parts of the Big Cypress Creek basin also have abundant red-slipped ceramics.

\section{Polished Plain}

Although identification is somewhat subjective, sherds with polished surfaces are tabulated separately. The sherds tend to be relatively thin and many have no visible temper (see Table 5), suggesting that undecorated portions of engraved vessels are abundantly represented in this group. No rim sherds are present in the polished plain wares.

\section{Other Undecorated}

Fifteen of the 97 rim sherds (15.5\%), and 562 (59.2\%) of the 949 body sherds are undecorated. Four of the undecorated rims appear to be from carinated bowls. The relatively low percentage of undecorated sherds is typical for Middle to Late Caddo period assemblages in this region. Temper was not recorded for these sherds. Many of the thickest sherds (9-14 mm) are flat and appear to represent vessel bases.

\section{Stone Artifacts}




\begin{tabular}{|l|r|r|r|r|r|r|r|}
\hline Table 5. Characteristics of body sherds. \\
\hline & No. & \multicolumn{1}{|c|}{ Grog } & \multicolumn{1}{|c|}{ bone } & shell & none & mean & s.d. \\
\hline & 26 & 18 & 8 & 0 & 0 & 6.12 & 1.03 \\
\hline Belcher Ridged, var. Belcher & 38 & 31 & 7 & 0 & 0 & 6.34 & 1.38 \\
\hline Belcher Ridged, var. Byram Ferry & 14 & 14 & 0 & 0 & 0 & 6.79 & 0.58 \\
\hline Belcher Ridged, var. Gore & 49 & 39 & 10 & 0 & 0 & 6.43 & 1.00 \\
\hline Pease Brushed-Incised & 1 & 1 & 0 & 0 & 0 & 7.00 & \\
\hline Hailey Complicated Incised & 1 & 1 & 0 & 0 & 0 & 6.00 & \\
\hline Harleton Appliquéd & 154 & 133 & 21 & 0 & 0 & 6.38 & 0.95 \\
\hline miscellaneous brushed & 10 & 9 & 1 & 0 & 0 & 5.60 & 0.52 \\
\hline miscellaneous appliqué & 32 & 25 & 7 & 0 & 0 & 6.31 & 0.97 \\
\hline miscellaneous ridged/brushed & & & & & & & \\
\hline & 8 & 3 & 3 & 1 & 1 & 5.38 & 1.19 \\
\hline Foster Trailed Incised & 1 & 1 & 0 & 0 & 0 & 8.00 & \\
\hline Mound Tract Incised and Brushed & 2 & 1 & 0 & 0 & 1 & 5.00 & 0.71 \\
\hline Cowhide Stamped & 4 & 2 & 2 & 0 & 0 & 6.50 & 2.52 \\
\hline miscellaneous incised & & & & & & & \\
\hline & 2 & 0 & 0 & 0 & 2 & 5.00 & 0.00 \\
\hline Glassell Engraved & 2 & 0 & 1 & 0 & 1 & 4.50 & 0.71 \\
\hline Hodges Engraved & 1 & 0 & 0 & 0 & 1 & 4.00 & \\
\hline Belcher Engraved & 47 & 10 & 8 & 0 & 29 & 5.85 & 0.93 \\
\hline miscellaneous engraved & & & & & & & \\
\hline & 1 & 1 & 0 & 0 & 0 & 5.00 & \\
\hline undecorated, red slipped & 100 & 56 & 6 & 2 & 36 & 5.97 & 1.30 \\
\hline undecorated, polished & 455 & & & & & 6.51 & 1.09 \\
\hline Undecorated & & & & & & & \\
\hline
\end{tabular}

\begin{tabular}{|l|c|c|}
\hline \multicolumn{3}{|c|}{ Table 6. Stone artifacts in the McKinney and Webb Collections. } \\
\hline & McKinney Collection & Webb Collection \\
\hline cortical flakes & 28 & 0 \\
\hline interior flakes & 17 & 0 \\
\hline pebble core & 10 & 0 \\
\hline pebble biface blank & 0 & 2 \\
\hline thick biface fragment & 1 & 2 \\
\hline quartz crystal fragment & 3 & 0 \\
\hline grinding slab & 1 & 0 \\
\hline pitted grinding stones & 0 & 2 \\
\hline pebble hammerstone & 0 & 1 \\
\hline celt fragments & 1 & 1 \\
\hline
\end{tabular}


It is doubtful that deposits were screened during the mound excavation and the McKinney collection probably is not representative of the actual quantities of flakes present. Webb rarely collected chipping debris in his surface collections. Overall, however, the stone artifact collection from the Byram Ferry site exhibits similarities to other floodplain Caddo sites in the region (Table 6). High proportions of cortical flakes, and many pebble cores reflect the dominant use of relatively small, local chert pebbles for stone tool manufacture. Pebble blanks suggest that arrow points and perhaps perforators were made at the site, although no completed specimens are present in the collections. Three quartz crystal fragments in the McKinney collection are of interest and might reflect special ceremonial activity associated with the use of the mound.

Grinding equipment is rarely plentiful at Caddo sites, but pitted grinding stones and small sandstone grinding slabs occur in the nearby Willow Chute Bayou area and at other floodplain sites. Celt fragments also are commonly found on local Caddo sites. The Byram Ferry specimens are typical for the area in that they are made of a grayish-green indurated quartzite that probably is from a source in the Ouachita Mountains.

\section{Artifacts from the 2003 Test Units}

A small number of artifacts was recovered in the auger and shovel tests conducted south of the existing mound in 2003. Sherds are similar to those in the McKinney and Webb collections (Table 7). Two Pease Brushed Incised and three brushed sherds were recovered. One sherd has multiple, parallel incised lines. The single engraved sherd is a portion of a negative scroll and likely relates to the type Hodges Engraved.

Chipping debris was relatively numerous (Table 8). Interestingly, the highest flake densities were recovered in the two shovel tests ( 1 and 2) into the disturbed deposits in the former mound area. It is apparent that flakes were not retained by the mound excavators. Of the 75 recovered flakes, seven are novaculite, two are fine-grained quartzite, and the remaining 65 are local cherts. Twenty-two flakes have some remaining cortex.

Also recovered were two small fragments of quartz crystals, a flake biface blank, and a pebble biface blank. The flake biface blank is a thick chert flake with bifacial retouch along portions of its margins. The specimen apparently was discarded before the margins were shaped into a specific form. The pebble blank is a small chert pebble with only portions of the cortex removed. One margin has been bifacially retouched, but the specimen does not appear to represent a finished tool.

\section{Table 7. Sherds from the 2003 investigations.}

\begin{tabular}{|l|r|r|r|r|r|r|r|r|}
\hline & ST1 & \multicolumn{1}{|c|}{ ST2 } & \multicolumn{1}{c|}{ ST3 } & \multicolumn{1}{|c|}{ ST4 } & \multicolumn{1}{c|}{ ST5 } & \multicolumn{1}{c|}{ AU1 } & Surface & \multicolumn{1}{|c|}{ Total } \\
\hline Pease Brushed Incised & 0 & 1 & 0 & 0 & 1 & 0 & 0 & 2 \\
\hline miscellaneous brushed & 1 & 0 & 1 & 0 & 0 & 0 & 1 & 3 \\
\hline miscellaneous incised & 0 & 0 & 0 & 0 & 0 & 0 & 1 & 1 \\
\hline Hodges Engraved & 0 & 0 & 1 & 0 & 0 & 0 & 0 & 1 \\
\hline Undecorated & 2 & 2 & 3 & 1 & 5 & 1 & 4 & 18 \\
\hline Total & 3 & 3 & 5 & 1 & 6 & 1 & 6 & 25 \\
\hline
\end{tabular}

Table 8. Stone artifacts from the 2003 investigations.

\begin{tabular}{|l|r|r|r|r|r|r|r|r|}
\hline & ST1 & ST2 & ST3 & ST4 & ST5 & AU1 & Surface & Total \\
\hline Flakes & 37 & 20 & 2 & 6 & 9 & 1 & 0 & 75 \\
\hline quartz crystal fragment & 1 & 0 & 1 & 0 & 0 & 0 & 0 & 2 \\
\hline flake biface blank & 0 & 0 & 0 & 0 & 0 & 0 & 1 & 1 \\
\hline pebble biface blank & 0 & 0 & 0 & 0 & 0 & 0 & 1 & 1 \\
\hline
\end{tabular}




\section{SUMMARY AND CONCLUSIONS}

The Byram Ferry site is one of the few remaining Caddo habitation and ceremonial centers in northwest Louisiana. Recent alluvium has capped most of the cultural deposits and it is likely that structural remains and other significant features are preserved. A poorly documented excavation in the 1950s destroyed one of the site's two mounds. The remaining mound has undergone negative impacts from erosion and a 20th century residence. However, the mound appears to have essentially the same size and shape as described in 1912 by C. B. Moore. Few recorded sites are present in the Red River floodplain in the immediate vicinity of Byram Ferry. Recent alluvium has buried old land surfaces and limited surface exposure of artifacts. Considerable subsurface testing will be necessary to identify the extent of habitation areas associated with the mounds.

Two known collections of sherds from the site have been described in this article. Clarence H. Webb made one collection around the surface of the small mound. The other is part of the Ralph McKinney collection and relates to excavation of the small mound during the 1950s. The collections are similar, and clearly show continuity in ceramic styles from the Middle to Late Caddo periods in this area. Particularly apparent is the transition in utilitarian jars from Pease Brushed Incised to Belcher Ridged with the Belcher Ridged var. Byram Ferry as a variant likely to be temporally, as well as stylistically, intermediate.

Two radiocarbon assays, one on charcoal from a test unit excavated in 2003, and another from charcoal retained by McKinney from the mound excavations, calibrate to the 15th century A.D. The mounds probably were built at approximately the same time as mound construction began at the Belcher site (16CD13), located approximately $25 \mathrm{~km}$ to the south (Webb 1959). At both sites, the mounds are located within a few meters of one another. However, the Belcher primary mounds eventually were combined into a single earthwork and

Belcher was occupied long after Byram Ferry was abandoned. The pairing of mounds at both sites during the 15th century suggests dualities in intra-community Caddo social organization at that time.

\section{ACKNOWLEDGEMENTS}

This study was carried out as part of the State of Louisiana's Regional Archaeology Program based at Northwestern State University of Louisiana. The program has been financed with state funds and with federal funds from the National Park Service, U.S. Department of the Interior. Thanks to Louis Baker who assisted with all aspects of the 2003 field studies, and to Mr. O. L. "Sonny" Gore for permission to conduct the test excavations. I also would like to thank the History Center of the Bossier Parish Library and the McKinney family for permission to analyze artifacts in the McKinney collection.

\section{REFERENCES CITED}

Gulf South Research Institute

1975 Red River Waterway, Louisiana, Texas, Arkansas, and Oklahoma. Mississippi River to Shreveport, Louisiana, and Shreveport, Louisiana to Daingerfield, Texas. Design memorandum No. 15, Analysis, Volume 5: Archaeology, History, and Culture. Report on file at the Louisiana Division of Archaeology, Baton Rouge. 
Kidder, Tristram R.

1988 Prehistoric and Early Historic Culture Dynamics in Southeast Arkansas and Northeast Louisiana, A.D. 1542-1730. Ph.D. dissertation, Department of Anthropology, Harvard University, Cambridge, Massachusetts.

Moore, Clarence B.

1912 Some Aboriginal Sites on Red River. Journal of the Academy of Natural Sciences of Philadelphia Volume 14 (Pt. 4), pp. 482-640.

Schambach, Frank F. and John E. Miller

1984 A Description and Analysis of the Ceramics. In Cedar Grove: An Interdisciplinary Investigation of a Late Caddo Farmstead in the Red River Valley, edited by Neal L. Trubowitz, pp. 109-170. Research Series No. 23. Arkansas Archeological Survey, Fayetteville.

Suhm, Dee Ann and Edward B. Jelks (editors)

1962 Handbook of Texas Archeology: Type Descriptions. The Texas Archeological Society, Special Publication No. 1 and The Texas Memorial Museum, Bulletin No. 4, Austin.

Webb, Clarence H.

1959 The Belcher Mound: A Stratified Caddoan Site in Caddo Parish, Louisiana. Society for American Archaeology Memoir 16, Salt Lake City.

1983 The Bossier Focus Revisited: Montgomery I, Werner and Other Unicomponent Sites. In Southeastern Natives and their Pasts, Papers Honoring Dr. Robert E. Bell, edited by Don G. Wyckoff and Jack L. Hofman, pp. 183240. Oklahoma Archeological Survey Studies in Oklahoma's Past No. 11 and Cross Timbers Heritage Association Contribution No. 2, Norman.

n.d. Unpublished field notes on file at Northwestern State University of Louisiana, Natchitoches.

Webb, Clarence H. and Ralph McKinney

1975 Mounds Plantation (16CD12), Caddo Parish, Louisiana. Louisiana Archaeology 2:39-127.

Weinstein, Richard A., David B. Kelley, and Joe W. Saunders

2003 Introduction. In The Louisiana and Arkansas Expeditions of Clarence Bloomfield Moore, edited by Richard A. Weinstein, David B. Kelley, and Joe W. Saunders, pp. 1-213. The University of Alabama Press, Tuscaloosa. 
